\title{
The Effect of Substrate Pre-treatment on Hydroxy-apatite Coated Titanium Alloy by High-velocity Oxy-fuel Process
}

\author{
Raden Dadan Ramdan ${ }^{1 *}$, Budi Prawara ${ }^{2}$, Rochim Suratman ${ }^{1}$, Ferdian Marta $^{1}$, Ali Rinaldi ${ }^{3}$ \\ ${ }^{1}$ Institut Teknologi Bandung, Materials Engineering Study Program, Bandung, 40132, Indonesia \\ ${ }^{2}$ P2 TELIMEK LIPI, Kompleks LIPI Jl. Sangkuriang Bandung, 40132, Indonesia \\ ${ }^{3}$ Chemistry Department, , King Fahd University of Petroleum and Minerals \\ Dhahran, 31261 Saudi Arabia, \\ Telp.: (022) 2508144, Fax: (022) 2508144 \\ E-mail: dadan@material.itb.ac.id
}

\begin{abstract}
In order to fully meet bio-compatibility requirement of titanium alloy as implant material, coating with hydroxyapatite (HA) is normally applied. The present research concerns on the effect of substrate pre-treatment on the coating of HA on titanium alloy by high-velocity oxy fuel process (HVOF). Before the coating, all samples were pre-treated by thermo-mechanical treatment in order to obtain fine grain structure. Three type of substrate pre-treatment is then applied on different substrates, including, sand-blasting, sand-blasting+etching, and sandblasting +etching + CNT intermediate layer. After coating, post-annealing treatment was applied on each sample and characterization was performed on the sample after the treatment. It was obtained that the sand-blasted sample has relatively rougher surface (SEM observation), lower degree of crystallinity (XRD characterization) and higher residual strain (XRD data calculation by Mud Master software) as compared with other samples. From FTIR characterization it can be obtained that all samples show no differences in orbital function.
\end{abstract}

Keywords: HAP coating, Titanium alloy, Substrate pre-treatment

\begin{abstract}
Abstrak
Untuk menyempurnakan persyaratan bio-kompatibilitas paduan titanium sebagai material implant, pelapisan paduan dengan hydroxyapatite (HA) biasa dilakukan. Penelitian ini fokus dalam mengevaluasi pengaruh dari pre-treatment terhadap substrat paduan titanium sebelum proses pelapisan HA dilakukan dengan metoda high-velocity oxy fuel process (HVOF). Sebelum pelapisan, semua sampel diberikan perlakuan thermomechanical treatment untuk mendapatkan butiran yang halus. Tiga jenis perlakuan permukaan diberikan kepada substrat meliputi, sand-blasting, sand-blasting+etching, dan sand-blasting+etching+ penambahan lapisan antara CNT. Setelah proses pelapisan, post-annealing treatment diberikan kepada setiap sampel dan beberapa karakterisasi dilakukan pada setiap sampel setelah perlakuan tersebut. Dari hasil karakterisasi SEM diperoleh bahwa sampel yang diberikan perlakuan permukaan berupa proses sand blasting saja mempunyai permukaan lapisan yang relatif lebih kasar dibandingkan dengan sampel lainnya. Selain itu dari karakterisasi XRD didapatkan bahwa sampel tersebut juga mempunyai derajat kristalinitas yang lebih rendah dan mempunyai regangan sisa yang lebih tinggi (dari perhitungan dengan Mud Master software atas data XRD) dibandingkan dengan sampel lainnya. Dari hasil FTIR diperoleh bahwa semua sampel tidak mempunyai perbedaan fungsi orbital antara satu dan lainnya..
\end{abstract}

Keywords: Pelapisan HAP, Paduan Titanium, Pre-treatment Substrat

\section{INTRODUCTION}

Titanium and its alloy have been regarded as material with superior mechanical properties such as high specific strength as well as excellent physical properties, i.e. corrosion resistance and enhanced biocompatibility [1,2]. Due to their high specific strength, titanium alloys are widely used in aerospace industries [3]. On the other hand due to combination between excellent mechanical properties and biocompatibility the alloys are potential to be used as orthopaedic implants [2]. post-annealing treatment was applied on each sample and characterization was performed on the sample after the treatment. It was 
obtained that the sand-blasted sample has relatively rougher surface (SEM observation), lower degree of crystallinity (XRD characterization) and higher residual strain (XRD data calculation by Mud Master software) as compared with other samples. From FTIR characterization it can be obtained that all samples show no differences in orbital function Coating and other surface modifications are required in order to improve implants osteointegration of titanium implants [5].

There are various method for coating of hydroxyapatite (HAP) on metal implant such as sol gel [6,7], thermal spray [8,9], electrophoretic deposition [10], deformation assist coating [11], etc. Among important method for the coating of HAP on titanium alloy is thermal spray method. Various type of thermal spray methods were reported applied for this purpose such as plasma spray and high-velocity oxy fuel process (HVOF). Since thermal spray involving high pressure and high temperature processes, investigation on the residual stresses of the coating is important [12]. On the other hand as an alternative to increase in vivo bioactivity and early bone growth, silica can be doped into the HAP coating [13].

In the present work HVOF coating was employed as the method to deposit HAP on titanium alloy substrate. For various reasons such as improving mechanical properties of HAP layer, mixing with other material with optimum composition can be performed [12]. Examples of materials that can be used in doping HAP coating are titania, carbon nano tube (CNT), zinc as well as silica as previously mentioned. Addition of zinc is expected to increase biocompatibility of HAP coating [13], whereas addition of CNT can increase the strength of the coating [14]. The present work focus in evaluating the effect of substrate pre-treatment on the HAP and HAP-CNT coating on titanium substrate by HVOF method.

\section{EXPERIMENTS}

\section{Coating Process}

In the present research, Ti6Al4V is used as the substrate material that was cut to cylinder shape with diameter of $1 \mathrm{~cm}$ and thickness of $1 \mathrm{~cm}$. Both carbon nano tube (CNT) and hydroxyapatite (HAP) were used in the form of powder and fed up to HVOF feedstock during the coating process. There are several surface treatment applied on the substrate before coating including sand blasting, etching and coating of CNT as intermediate coating layer. For blasting process alumina is used as the grit materials with particle size of $1.2 \mathrm{~mm}$, whereas spraying angle at $90^{\circ} \mathrm{C}$ and distance between spraying gun and substrate surface is $170 \mathrm{~mm}$. On the other hand etching process is performed by immersing the specimen on the sulfate acid solution with the composition of $48 \%$ sulfate acid and $52 \%$ water. In addition, CNT intermediate layer was obtained by HVOF method which was performed before HAP coating by the same method.

HAP coatings by HVOF method were performed subsequently after the above surface treatment of the substrate. Before the process, substrates were pre-heated by flame from HVOF gun and temperature of pre-heated surface is less than $150^{\circ} \mathrm{C}$, whereas distance between HVOF gun and substrate surface is about $250 \mathrm{~mm}$. After spray coating, specimens were cooled down by air spraying through HVOF gun up to temperature approaching room temperature. After the coating process, specimens were post-heat-treated at temperature of $600^{\circ} \mathrm{C}$ for 2 hours. This heat treatment was performed in order to enhance the bonding strength of the coating by allowing diffusion of coating layer into substrate.

\section{Characterization}

Several characterizations were performed on the resulted coating layer including scanning electron microscope (SEM) for morphology evaluation, X-ray diffraction (XRD) characterization for crystal structure and residual strain measurement (from XRD data calculation by MUD MASTER software) and FTIR characterization for functional group characterization. The latter was also performed in order to confirm that the substrate pre-treatments conducted in the present research will not change the chemistry of the HAP coated layer.

For the case of residual strain measurement by Mud Master software, the software calculate the crystal size by utilizing XRD data. By this calculation crystal strain can be obtained from the variation of crystal size (d) of different plane. This value of strain can be converted to stress value which gives more meaningful value for various purposes.

\section{RESULTS AND DISCUSSION}

Figure 1 shows cross section substrate surface 
morphology of sand blasted samples, without and with etching process. It can be seen from the figure, finer and more homogeneous substrate surfaces are obtained for the etched samples. This condition is predicted due to the formation of solid compound between etchant and alloy components that covers the substrate surface.

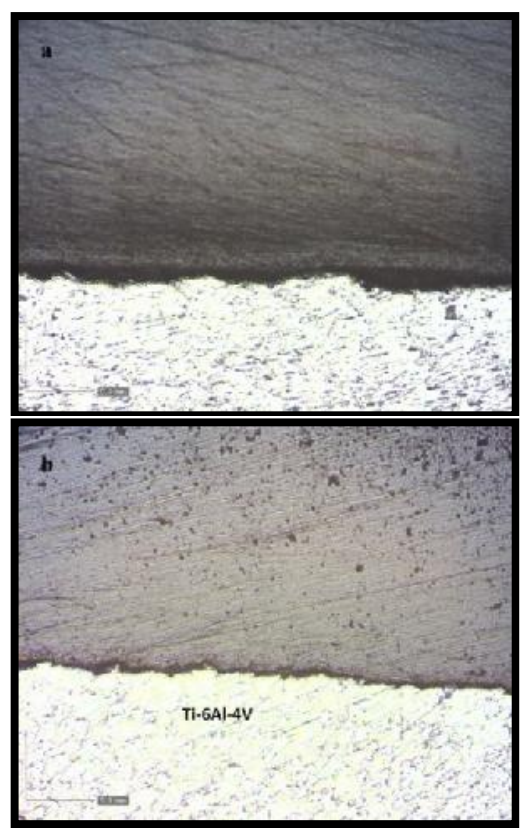

Figure.1 Morphology of substrate surface after sand blasting process (a) without etching (b) with etching process

In addition, Figure 2 shows scanning electron micrograph of coated layer prepared by only sand blasting process (Figure 2(a)), by sandblasting+etching process (Figure 2(b)) and by sand blasting +etching+intermediate CNT layer (Figure 2(c)). It can be seen from the first sample wide and depth coarse surface structure observed (circled), whereas this features cannot be observed on other samples. This condition is in accordance with Figure 1 , that the non-etched sample has coarser structure as compared to etched sample.

On the other hand Figure 3 (a), (b) and (c) shows x-ray diffractograph of the sand blasted+etched+CNT sample (sample 1), blasted+etched (sample 2) and blasted sample (sample 3) respectively. It can be seen from the figure that qualitatively sample 1 and 2 show less scattered pattern with higher peak intensities of HAP as well. This condition suggests that both etching and introducing CNT intermediate layer contribute in improving the crystallinity of HAP coated layer. In addition by comparing XRD pattern of samples 1 and 2 , it can be seen that introducing intermediate layer CNT further increase the crystallinity of the HAP coated layer.

Table 1 Residual strain valued from XRD data calculation by MUD MASTER software

\begin{tabular}{|c|c|}
\hline Samples & $\begin{array}{c}\text { Residual } \\
\text { strain }\end{array}$ \\
\hline blasted + etching & 0 \\
\hline Blasted+CNT+etching & 0 \\
\hline blasted & 0.218 \\
\hline
\end{tabular}

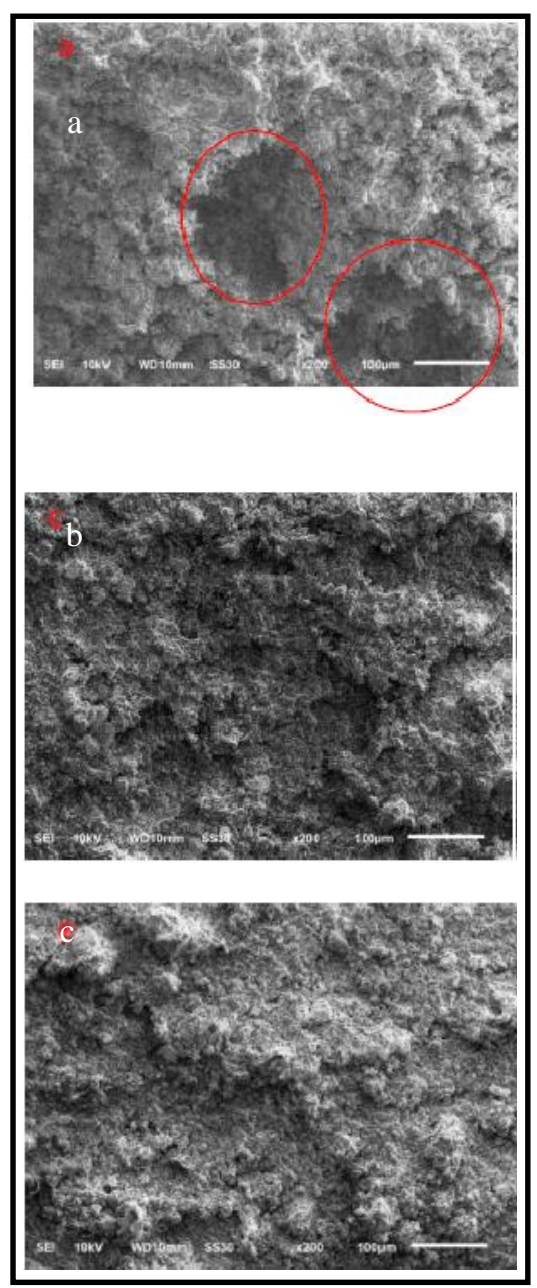

Figure 2 SEM of coated samples (a) sand blasted sample (b) sand-blasted and etched sample (c) sand blasted, etched with intermediate CNT layer

From residual strain calculation of XRD data by 
MUD MASTER software, it was obtained decreasing residual strain of the HAP coated layer for the blasted+etched samples and blasted+etched+CNT samples. This condition is in accordance with qualitative observation on the XRD data in the Figure 3 that higher crystallinity obtained for these samples. This condition is also predicted due to the different surface morphology of the coating as shown in the Figure 1 and 2. Therefore it is considered that different substrate pre-treatment influence the surface contour of the coated layer and in turn influences the crystallinity as well as residual strain of the layer. And further, the latter fact might also affect the adhesion properties of the coated layer.

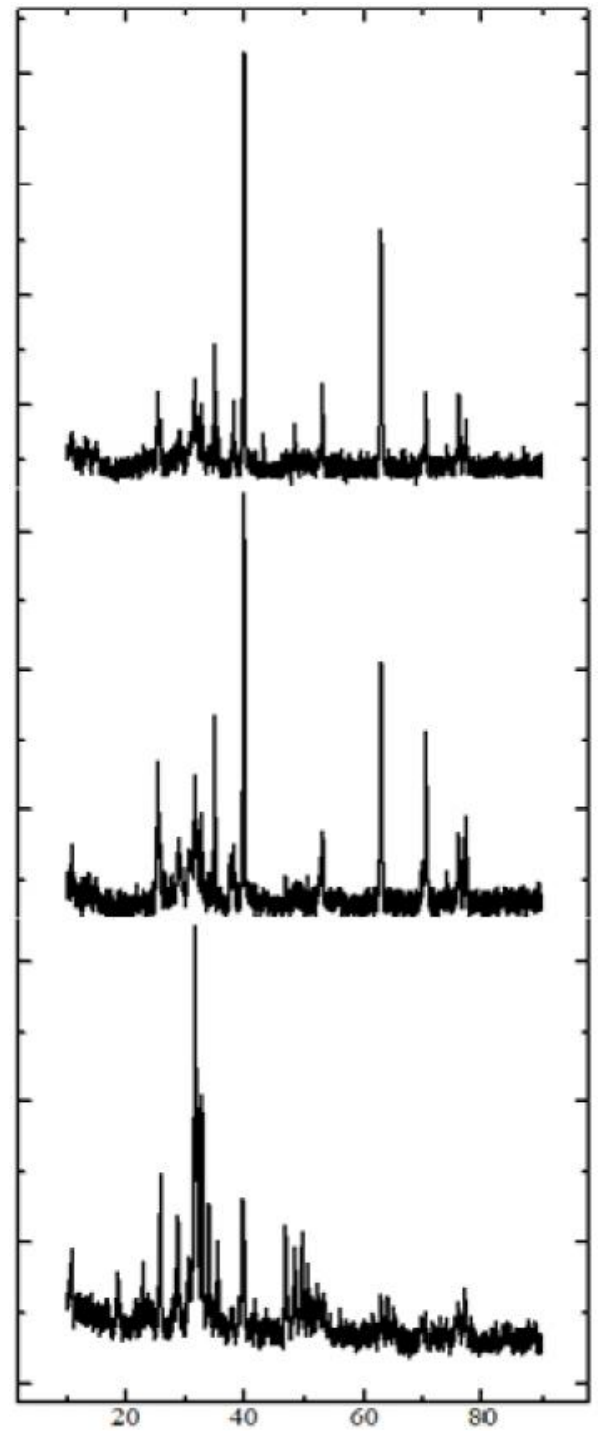

Figure 3 X-ray diffractograph of coated samples(a) sand blasted, etched with intermediate CNT layer (b) sand-blasted and etched sample (c) sand blasted sample

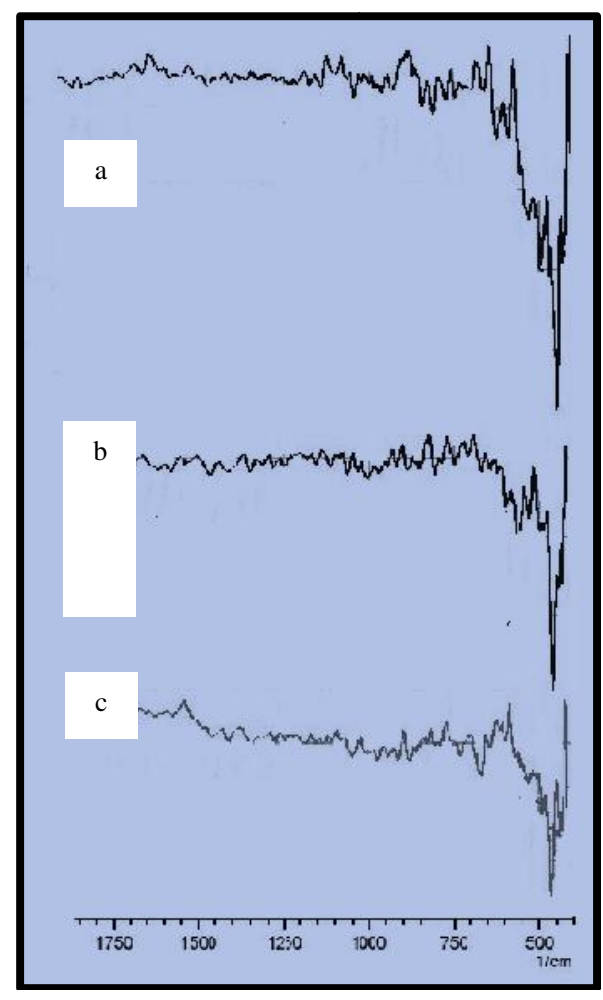

Figure 4 FTIR data of coated samples (a) sand-blasted and etched sample (b) sand blasted, etched with intermediate CNT layer (c) sand blasted sample

In addition Figure 4 shows FTIR data for all samples, showing the sharp peak of IR spectrum of all. For hydroxyapatite, the orbital functions that are normally identified by FTIR characterization including phosphate $\left(\mathrm{PO}_{4}{ }^{3-}\right)$, hydroxyl $\left(\mathrm{OH}^{-}\right)$and carbonate $\left(\mathrm{CO}_{3}{ }^{2-}\right)$. For the case of sample 3, phosphate was identified at the wave number of 500 $630 \mathrm{~cm}^{-1}$, hydroxyl at 644 and $1672.9 \mathrm{~cm}^{-1}$, whereas carbonate at 1276, 1350, 1409 and $1460 \mathrm{~cm}^{-1}$. On the other hand for the sample 2, phosphate was identified at the wave number of $449 \mathrm{~cm}^{-1}$, hydroxyl at $626 \mathrm{~cm}^{-1}$ and carbonate at $929 \mathrm{~cm}^{-1}$. In addition for the Sample 1 , beside phosphate at $459 \mathrm{~cm}^{-1}$, hydroxyl at 1678 and carbonate at 1346,1415 and $1463 \mathrm{~cm}^{-1}$, TCP phase which is secondary phase from decomposition of HAP was also observed at 563.21 and $597 \mathrm{~cm}^{-1}$. The appearance of TCP phase in the blasted samples indicates thermal instability of HAP layer of this sample. On the other words, in can also be 
considered that both etching and introducing intermediate CNT layer produce higher thermal stability of the coated layer and in turn avoid the transformation of HAP to TCHP phase. For all samples phosphate peaks shows the highest peaks, which indicate the composition of this compound are highest of all. Overall these FTIR data confirm that all the coated layers have the common orbital function of HAP, and therefore the substrate pretreatment performed in the present research will not alter the chemistry of the HAP coated layer.

\section{CONCLUSION}

Hydroxy apatite coating on titanium substrates have been performed with various substrate surface pre-treatment as the parameter to be optimized. It was obtained that etching treatment following sandblasting treatment on the substrate produces finer substrate surface. This condition induces in the finer morphology of the coating layer and in turn decreases the residual strain of the coating layer. It was also observed from XRD data that coated samples with CNT intermediate layer shows highest crystallinity. FTIR characterizations confirm the formation of HAP orbital function in all samples and it was also confirmed higher thermal stability on the etched sample and sample with CNT intermediate layer than the blasted sample. From FTIR characterization it was also confirm that substrate pre-treatment applied in the present research will not alter the chemistry of the coated HAP layer.

\section{ACKNOWLEDGEMENT}

To the Faculty of Mechanical and Aerospace Engineering Institute of Technology Bandung Indonesia, for the support in publishing the present paper.

\section{REFERENCES}

[1] Y. Wang, H. Yu, C. Chen, Z. Zhao, Mater. and Des. 85 (2015) 640

[2] J. Fojt, V. Filip, L. Joska, Appl. Surf. Sci. 355 (2015) 52

[3] N. Khanna, J.P. Davim, Measurement. 61 (2015) 280

[4] B. Ben-Nissan, A.H. Choi, R. Roest, B.A. Latella, A. Bendavid, Hydroxyapatite (Hap) for Biomed. Applications, (2015)21
[5] Kwa'sniak, J. Pura, M. Zwoli’nska, P. Wieci'nskia, H. Skar'zy'nski, L. Olszewski, J. Marczak, H. Garbacz, K.J. Kurzydłowski, Appl. Surf. Sci. 336 (2015) 267

[6] R. Rojaee, M. Fathi, K. Raeissi, Mater. Sci. and Eng.: C, Volume 33( 7) (2013) 3817

[7] D. Sidane, D. Chicot, S. Yala, S. Ziani, H. Khireddine, A. Iost, X. Decoopman, Thin Solid Films. 593 (2015) 71

[8] A.R. Nimkerdphol, Y. Otsuka, Y. Mutoh, J.of the mech. behave. of biomed. Mater. 36(2014) 98

[9] E. SáraBogya, Z. Károly, R. Barabás, Ceram. Inter. 41(2015) 6005

[10] [K. P. Ananth, A. J. Nathanael, S. P. Jose, T. H. Oh, D. Mangalaraj, A.M. Ballamurugan, Appl. Surf. Sci. 353(2015) 189

[11] R.D. Ramdan, I. Jauhari, R Hasan, N.R.N. Masdek, Mater.Sci. and Eng.: A 477 (1) 300

[12] H. Melero, G. Fargas, N. Garcia-Giralt, J. Fernández, J.M. Guilemany, Surf. \& Coat. Tech. 242 (2014) 92

[13] Z. Zhong, J.L Qin, J. Ma, Ceram. Int. 41(2015) 8878 